$1-2016$

\title{
Achieving Sex-Representative International Court Benches
}

Nienke Grossman

University of Baltimore School of Law, ngrossman@ubalt.edu

Follow this and additional works at: http://scholarworks.law.ubalt.edu/all_fac

Part of the International Law Commons, Judges Commons, and the Law and Gender Commons

\section{Recommended Citation}

Nienke Grossman, Achieving Sex-Representative International Court Benches, 110 Am. J. Int'l L. 82 (2016).

This Article is brought to you for free and open access by the Faculty Scholarship at ScholarWorks@University of Baltimore School of Law. It has been accepted for inclusion in All Faculty Scholarship by an authorized administrator of ScholarWorks@University of Baltimore School of Law. For more information, please contact snolan@ubalt.edu. 


\title{
This article is reproduced with permission from the January 2016 issue of the American Journal of International Law @ 2016 American Society of International Law. All rights reserved.
}

\section{NOTES AND COMMENTS}

\section{ACHIEVING SEX-REPRESENTATIVE INTERNATIONAL COURT BENCHES}

\author{
By Nienke Grossman*
}

Twenty-five years ago, in this Journal, Hilary Charlesworth, Christine Chinkin, and Shelley Wright argued that the structures of international law "privilege men." ${ }^{1}$ As shown in Table 1, which summarizes data from a forthcoming article, on nine of twelve international courts of varied size, subject-matter jurisdiction, and global and regional membership, women made up 20 percent or less of the bench in mid $2015 .^{2}$ On many of these courts, the percentage of women on the bench has stayed constant, vacillated, or even declined over time. ${ }^{3}$ Women made up a lower percentage of the bench in mid 2015 than in previous years on two-thirds of the courts surveyed. ${ }^{4}$

For courts where states were required by statute to take sex into account when nominating or voting for judges, a higher percentage of women sat on the bench in mid 2015. Examples include the International Criminal Court (ICC), the European Court of Human Rights (ECHR), the African Court on Human and Peoples' Rights, and the ad litem benches of the International Criminal Tribunals for Rwanda and the Former Yugoslavia (ICTR and ICTY, respectively). Thirty-two percent of the judges on these courts were women in mid 2015. Where a "fair representation" of the sexes was not aspired to or required, women made up only 15 percent of the bench.

\footnotetext{
* Associate Professor of Law, University of Baltimore School of Law; Deputy Director, Center for International and Comparative Law. I would like to thank for their comments and feedback on this project Cindy Galway Buys, Harlan Grant Cohen, Susan Franck, Claudio Grossman, Audrey McFarlane, Darren Rosenblum, Colin Starger, Eric Voeten, and Markus Wagner. I am grateful for comments received at the New York University Colloquium on International Law and Justice, the Junior International Law Scholars Association meeting at the University of California, Berkeley, the Association of American Law Schools Workshop on Transnational Perspectives on Equality Law, and the University of Bruxelles "Le juge est une femme" conference, as well as for research assistance from Harvey Morrell and Adeen Postdar. I also wish to thank Irene Klinger and Ezequiel Steiner for their support and encouragement throughout this project.

${ }^{1}$ Hilary Charlesworth, Christine Chinkin \& Shelley Wright, Feminist Approaches to International Law, 85 AJIL 613 (1991).

${ }^{2}$ For a more comprehensive description of the data presented in this article and its sources, see Nienke Grossman, Shattering the Glass Ceiling in International Adjudication, 56 VA. J. INT'L L. 213 (forthcoming 2016).

${ }^{3}$ Id.

${ }^{4} \mathrm{Id}$. Although not the focus of this article, women are also found in low numbers in investor-state dispute resolution. Only 6.5 percent of known investment treaty arbitration appointments were women until May 2010. Two women, Gabrielle Kaufmann-Kohler and Brigitte Stern, accounted for 75 percent of female appointments, whereas the two most frequently appointed men accounted for 5 percent of the appointments of male arbitrators. See, e.g., Gus van Harten, The (Lack of) Women Arbitrators in Investment Treaty Arbitration, 59 COLUM. FDI PERSP. (Feb. 6, 2012); see also Susan D. Franck, James Freda, Kellen Lavin, Tobias Lehmann \& Anne van Aaken, The Diversity Challenge: Exploring the “Invisible College" of International Arbitration, 53 COLUM. J. TRANSNAT'L L. 429, 430 (2015) (finding through a survey of attendees at the Congress of the International Council for Commercial Arbitration that 17.6 percent of arbitrators were women).
} 
TABLE 1

SUMMARY CHART ON THE PAUCITY OF WOMEN JUDGES ON INTERNATIONAL COURTS

\begin{tabular}{|c|c|c|c|c|c|c|}
\hline Court & $\begin{array}{l}\text { Women in } \\
\text { Mid } 2015 \\
\quad(\%)\end{array}$ & $\begin{array}{l}\text { Slots Occupied } \\
\text { by Women } \\
\text { from } 1999 \text { to } \\
\text { Mid } 2015(\%)\end{array}$ & $\begin{array}{l}\text { Representation } \\
\text { Requirement? }\end{array}$ & $\begin{array}{c}\text { Level of } \\
\text { Guidance or } \\
\text { Transparency } \\
\text { at National } \\
\text { Level }\end{array}$ & $\begin{array}{c}\text { Institutional } \\
\text { Screening }\end{array}$ & $\begin{array}{c}\text { Year } \\
\text { Established }\end{array}$ \\
\hline $\begin{array}{c}\text { African Court on } \\
\text { Human and } \\
\text { People's Rights }\end{array}$ & 2/11 (18\%) & $18 \%$ & $\begin{array}{l}\text { Yes: } \\
\text { aspirational }\end{array}$ & Lower & No & 2006 \\
\hline $\begin{array}{l}\text { Andean Tribunal } \\
\text { of Justice }\end{array}$ & $2 / 4(50 \%)$ & $17 \%$ & No & Lower & No & 1984 \\
\hline $\begin{array}{l}\text { Appellate Body of } \\
\text { the World Trade } \\
\text { Organization }\end{array}$ & $1 / 7(14 \%)$ & $17 \%$ & No & Lower & Yes & 1995 \\
\hline $\begin{array}{l}\text { Court of Justice for } \\
\text { the Economic } \\
\text { Community of } \\
\text { West African } \\
\text { States }\end{array}$ & $1 / 7(14 \%)$ & $40 \%$ & No & N/A & Yes & 2001 \\
\hline $\begin{array}{l}\text { European Court } \\
\text { of Human } \\
\text { Rights }\end{array}$ & $15 / 45(33 \%)$ & $29 \%$ & $\begin{array}{l}\text { Yes: } \\
\text { aspirational } \\
\text { 1999-2003; } \\
\text { virtually } \\
\text { mandatory } \\
\text { since 2004 }\end{array}$ & Higher & Yes & 1959 \\
\hline $\begin{array}{l}\text { European Court of } \\
\text { Justice }\end{array}$ & $5 / 28(18 \%)$ & $14 \%$ & No & Higher & N/A & 1952 \\
\hline $\begin{array}{l}\text { Inter-American } \\
\text { Court of } \\
\text { Human Rights }\end{array}$ & $1 / 7(14 \%)^{\mathrm{a}}$ & $16 \%$ & No & Lower & No & 1979 \\
\hline $\begin{array}{l}\text { International } \\
\text { Court of Justice }\end{array}$ & $3 / 15(20 \%)$ & $11 \%$ & No & Lower & No & 1946 \\
\hline $\begin{array}{l}\text { International } \\
\text { Criminal Court }\end{array}$ & 7/18 (39\%) & $47 \%$ & $\begin{array}{l}\text { Yes: } \\
\text { mandatory }\end{array}$ & Lower & Yes & 2003 \\
\hline $\begin{array}{l}\text { International } \\
\text { Criminal } \\
\text { Tribunal for the } \\
\text { Former } \\
\text { Yugoslavia }\end{array}$ & $\begin{array}{l}\text { Permanent: } \\
\text { 2/19 } \\
\quad(11 \%) \\
\text { Ad litem: } 1 / 3 \\
\quad(33 \%)\end{array}$ & $\begin{array}{l}\text { Permanent: } \\
\text { 11\% } \\
\text { Ad litem: } 41 \%\end{array}$ & $\begin{array}{l}\text { Yes: } \\
\text { aspirational } \\
\text { for ad litem } \\
\text { only }\end{array}$ & Lower & No & 1993 \\
\hline $\begin{array}{l}\text { International } \\
\text { Criminal } \\
\text { Tribunal for } \\
\text { Rwanda }\end{array}$ & $\begin{array}{l}\text { Permanent: } \\
\text { 2/9 (22\%) } \\
\text { Ad litem: } 0 / 1 \\
(0 \%)\end{array}$ & $\begin{array}{l}\text { Permanent: } \\
22 \% \\
\text { Ad litem: } 35 \%\end{array}$ & $\begin{array}{l}\text { Yes: } \\
\text { aspirational } \\
\text { for ad litem } \\
\text { only }\end{array}$ & Lower & No & 1996 \\
\hline $\begin{array}{l}\text { International } \\
\text { Tribunal for the } \\
\text { Law of the Sea }\end{array}$ & $1 / 21(5 \%)$ & $2 \%$ & No & Lower & No & 1996 \\
\hline
\end{tabular}

${ }^{\text {a }}$ In mid 2015, no women were on the Inter-American Court of Human Rights, but because one woman was elected to join the Court starting in 2016, she is included here. 
From 1999 to 2015, four of the five courts with the highest percentages of judicial slots occupied by women had either mandatory or aspirational language in their statutes or selection rules. The year 1999 was the first in which any of the surveyed courts had such language. Percentages were obtained by dividing the total number of slots occupied by women each year by the total number of slots occupied by both men and women each year. None of the seven courts with the lowest percentages of women on the bench in the same period had sex-representation requirements or aspirations.

The character and quality of selection procedures may also play a role in the percentage of women on the bench. It is difficult to draw statistically significant conclusions about the impact of increased transparency or statutory guidance on national nomination procedures since neither is found in the vast majority of nomination procedures, and the sample size of twelve courts is small. Nonetheless, a lack of transparency and the closed nature of nomination processes on most international courts may depress the percentage of women on the bench overall. ${ }^{5}$ By contrast, institutionalized screening after nomination may increase balance on the bench. For example, from 1999 until mid 2015, women occupied 29 percent, 40 percent, and 47 percent of judicial slots on the ECHR, the Court of Justice for the Economic Community of West African States (ECOWAS), and the ICC respectively-three of the four courts with institutionalized screening after nomination. But on the fourth court-the Appellate Body of the World Trade Organization (W TO) — women sat on the bench only 17 percent of the time.

In isolation the data on the percentage of women serving on these courts do not necessarily support Charlesworth, Chinkin, and Wright's thesis of institutionalized male privilege in relation to international courts; instead, they could reflect low numbers of qualified female candidates in the pool of candidates, explaining proportionately low numbers on international court benches. Yet, as discussed in part II below, the limited-pool argument is unpersuasive for a number of reasons, including the limited role that merit plays in international judicial selection procedures and the constant or declining percentage of female judges over time on some courts as the pool has grown. In addition, many states with higher percentages of female lawyers do not seat more international women judges.

States should take remedial steps to increase sex representativeness on the bench, both to comply with their international legal obligations and to buoy the legitimacy of international courts (part III). Reforms, described in part IV, might include making selection procedures more open, transparent, and merit based. Alternatively, states could signal their desire for sexrepresentative benches through aspirational statements incorporated into court statutes or selection procedures, or through temporary special measures or quotas (part V). A quarter century after the publication of "Feminist Approaches to International Law," the time is ripe to achieve sex-representative international court benches.

\section{The Pool of AVAilable CANDidates}

A shallow pool of qualified female candidates is a poor explanation for the overrepresentation of men on international courts. The pool argument provides that women are found in lower numbers on courts without quotas because not enough qualified women are available to

5 See infra part III.

${ }^{6}$ Charlesworth et al., supra note 1. 
occupy these prestigious positions. But if the pool were the reason for the paucity of women judges, one might anticipate that the number of women on the bench would grow as women enter law schools, the diplomatic corps, and the legal profession in greater numbers. This is not the case for many international courts.

For the first fifteen years following the establishment of the International Tribunal for the Law of the Sea (ITLOS) in 1996, no woman served on the 21-member bench. Since then, only one woman has served (Judge Elsa Kelly from Argentina), accounting for 2.5 percent of all ITLOS judges. ${ }^{7}$ The number of women judges on the African Court on Human and Peoples' Rights has stayed constant at two of eleven since its establishment in 2006. In total, four of the twenty-two African Court judges, or 18 percent, have been women. ${ }^{8}$ On eight of the twelve courts surveyed, a lower percentage of women sat on the bench in mid 2015 than in previous years. On some courts, the decline is dramatic. For example, in 2004, women accounted for 60 percent of the ICTR's ad litem bench, but since then that percentage has dropped precipitously; in 2011, only 20 percent of the ad litem judges were women. The Inter-American Court of Human Rights (IACHR) had as many as three female judges out of seven judges (43 percent) only a few years ago. The number then dropped to two and then to zero. One female judge was elected to the seven-member bench in the last round of elections. Women made up over 40 percent of the WTO Appellate Body only a few years ago, but in mid 2015, only one woman sat on the seven-member bench. The same applies to ECOWAS.

If the pool argument were correct, one might expect that courts with similar subject-matter jurisdiction would have similar percentages of women on the bench. Yet, the ICC had 39 percent women on the bench in mid 2015, whereas the ICTR had 22 percent permanent female judges, and the ICTY, 11 percent. In addition, between 1999 and 2015, women held 41 percent of ad litem slots on the ICTY bench but only 11 percent of permanent slots. In the same period, women held 35 percent of ad litem slots on the ICTR but only 22 percent of permanent ones.

Using the percentage of women lawyers in a country as a proxy for the pool, one might expect that states with a higher percentage of women lawyers would have a higher percentage of women judges. For many states, this does not appear to be the case. For example, no French woman has served as a permanent judge on the European Court of Justice, the International Court of Justice (ICJ), ECHR, ICC, ICTR, ICTY, or ITLOS-although twenty-five men have. ${ }^{9}$ Fifty percent of France's lawyers are estimated to be female. ${ }^{10}$ Twenty-four British men and one British woman have served on the European Court of Justice, ICC, ICJ, ECHR, and

\footnotetext{
7 Members of the Tribunal Since 1996, at https://www.itlos.org/the-tribunal/members-of-the-tribunal-since$1996 /$.

${ }^{8}$ See Judges of the Court, at http://www.african-court.org/en/index.php/about-the-court/jurisdiction-3/judges.

9 Seven men have served on the European Court of Justice, including one for two separate terms. Five men have served on the European Court of Human Rights (ECHR). One man has served on the International Tribunal for the Law of the Sea (ITLOS). Five men have served on the International Court of Justice (ICJ) as permanent judges. Three men have served as permanent judges on the International Criminal Tribunal for the Former Yugoslavia (ICTY), and one of them (Claude Jorda) also served on the joint appeals chamber for the International Criminal Tribunal for Rwanda (ICTR) and the ICTY. Three men have served on the International Criminal Court (ICC). One woman, Michele Picard, served as an ad litem judge on the ICTY. The data was drawn from the court websites referenced in Grossman, supra note 2, at 223 n.43.

${ }^{10}$ Ethan Michelson, Women in the Legal Profession, 1970-2010: A Study of the Global Supply of Lawyers, 20 IND. J. GLOBAL LEGAL STUD. 1071, T. A6 (2013).
} 
ICTY. ${ }^{11}$ About half of the United Kingdom's lawyers are estimated to be women. ${ }^{12}$ No Russian woman served on any of the five international courts on which Russian men served, although about half of Russia's lawyers are women. ${ }^{13}$ By contrast, China has appointed one woman each to the WTO Appellate Body and ICJ, and seven men to the ICJ, ICTR, and ICTY. ${ }^{14}$ About one-fifth of China's lawyers are female. ${ }^{15}$

The limited-pool argument assumes that judicial selection procedures aim to choose the most meritorious candidates. Yet, international judgeships are often used to reward political loyalty or to advance political agendas, rather than to select the most qualified or meritorious candidates. ${ }^{16}$ A recent election to the IACHR illustrates the point. While praising the "long and deep commitment to human rights" of one judicial candidate, an independent panel expressed grave concerns about another candidate's ability to remain impartial and independent with respect to his country's human rights record. ${ }^{17}$ The former lost the election, and the latter replaced him on the bench. In the same vein, one study showed that eight of twenty-five judges at the ICTY and the shared ICTY/ICTR appeals chamber had no prior criminal judicial experience. Many of them had no experience in international criminal law, and many did not have even fifteen years of relevant professional experience. ${ }^{18}$ Also, it is widely acknowledged that international judicial elections are often the result of political horse-trading among states. ${ }^{19}$ States trade votes for their candidates across a number of international courts. Such an international election system does not require any analysis of a candidate's qualifications. The pool argument loses much of its purchase if merit is not the driving factor in the international judgeselection process.

Finally, about 195 judges sit on the twelve benches surveyed in this study. Openings happen periodically on each of them. The pool need not be large to increase the percentage of international judgeships filled by women. Alternatively stated, it is difficult to believe that in a world of over 7 billion people, only one woman is qualified to sit on the seven-member benches of the ECOWAS, IACHR, and WTO Appellate Body, and on the 21-member bench of ITLOS.

${ }^{11}$ Six men have served on the European Court of Justice, whereas two served on the ICC. Seven served on the ECHR, and three served on the ICTY as permanent judges. Six men and one woman, Rosalyn Higgins, have served as judges on the ICJ bench. See Grossman, supra note 2, at 223 n.43.

12 Michelson, supra note 10.

${ }^{13}$ Id. Three men have served on the ECHR. On the ICJ, five men served on behalf of the Union of Soviet Socialist Republics and four on behalf of the Russian Federation. Two men were judges for ITLOS, and three for the ICTY and ICTR combined. See Grossman, supra note 2, at 223 n. 43.

14 Four men have served on the ICJ, and three on the ICTY and ICTR combined. One woman serves on the ICJ and one on the World Trade Organization's Appellate body. See Grossman, supra note 2, at 223 n.43.

15 Michelson, supra note 10.

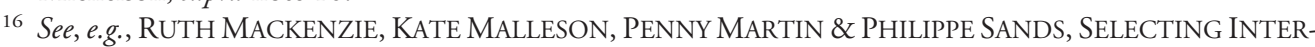
NAtional Judges: PrinciPle, Process, AND POlitics 95 (2010); Cherie Booth \& Philippe Sands, Keep Politics out of the Global Courts, GUARDIAN (UK) (July 13, 2001).

17 FINAL REPORT OF THE INDEPENDENT PANEL FOR THE ELECTION OF INTER-AMERICAN COMMISSIONERS AND JUDGES 25-26, 29 (June 2, 2015), at http://www.opensocietyfoundations.org/sites/default/files/iachrpanel-report-eng-20150603.pdf.

18 Michael Bohlander, The International Criminal Judiciary_Problems of Judicial Selection, Independence and Ethics, in INTERNATIONAL CRIMINAL JUSTICE: A CRITICAL ANALYSIS OF INSTITUTIONS AND PROCEDURES 354 (Michael Bohlander ed., 2007).

19 See, e.g., 1 SHABTAi Rosenne, THE LAW AND PRACTICE OF THE INTERNATIONAL COURT, 1920-2005, at 384 (2006); Ruth MacKenzie \& Philippe Sands, International Courts and Tribunals and the Independence of the International Judge, 44 HARV. INT'L L.J. 271, 271-72 (2003). 


\section{Why States Must ACT To ReMEdy SEX-UnREPRESENTATIVE BENCHES}

States are legally required to take steps to understand and remedy the paucity of women judges on most international court benches. The UN Charter declares that the United Nations "shall place no restrictions on the eligibility of men and women to participate in any capacity and under conditions of equality in its principal and subsidiary organs." ${ }^{20}$ The ICJ is the United Nations' "principal judicial organ," as described in the Charter. ${ }^{21}$ The ICTR and ICTY are both creations and subsidiary organs of the UN Security Council. ${ }^{22}$ Although the ICC was not created by the Council, it has a unique relationship with the United Nations. Pursuant to its Chapter VII powers - the same basis for establishing the ICTR and the ICTY - the Council can refer situations to the ICC in the absence of the usual temporal, personal, and territorial jurisdictional requirements. ${ }^{23}$ Also, the Negotiated Relationship Agreement Between the International Criminal Court and the United Nations established links between the two institutions, including close cooperation on personnel standards and a number of administrative matters. ${ }^{24}$ Given this relationship, the UN Charter's provisions on equality at least arguably apply to the ICC and also to the ICJ, ICTR, and ICTY. ${ }^{25}$

States' obligation to remedy skewed international court benches extends beyond courts that are tied to the UN system. Several human rights treaties require states to act in favor of equality of the sexes regarding participation in public life. For example, Article 25 of the International Covenant on Civil and Political Rights provides that states will "undertake to ensure the equal rights of men and women to the enjoyment of all civil and political rights" found in the covenant, including access on "general terms of equality" to public service. ${ }^{26}$ Regional human rights instruments impose similar obligations. ${ }^{27}$ In the Convention on the Elimination of Discrimination Against Women, Article 8 requires states to take appropriate measures to "ensure

${ }^{20}$ UN Charter, Art. 8. The preamble "reaffirm [s] faith in fundamental human rights, in the dignity and worth of the human person, in the equal rights of men and women and of nations large and small."

21 Id., Art. 92.

22 SC Res. 827 (May 25, 1993) (ICTY); SC Res. 955 (Nov. 8, 1994) (ICTR); The United Nations System Chart (2015), at http://www.un.org/en/aboutun/structure/pdfs/UN_System_Chart_30June2015.pdf.

23 Rome Statute of the International Criminal Court, Art. 13(b), July 17, 1998, 2187 UNTS 90.

${ }^{24}$ Negotiated Relationship Agreement Between the International Criminal Court and the United Nations, ICC Doc. ICC-ASP/3/Res.1 (Oct. 4, 2004).

${ }^{25}$ Furthermore, in the 1995 Beijing Platform for Action, states made political commitments to "[a]im at gender balance in the lists of national candidates nominated for election or appointment to United Nations bodies, specialized agencies and other autonomous organizations of the United Nations system." Platform for Action, para. 190(j) (Sept. 15, 1995), in Report of the Fourth World Conference on Women, UN Doc. A/CONF.177/20/Rev.1, ch. I, Res. 1, Annex II (1996).

26 International Covenant on Civil and Political Rights, Arts. 3, 25, Dec. 16, 1966, 999 UNTS 171.

27 See, e.g., American Convention on Human Rights, Art. 23, Nov. 22, 1969, OASTS No. B-32, 1144 UNTS 123 (Every citizen has the right and opportunity to "take part in the conduct of public affairs" and "to have access, under general conditions of equality, to the public service of his country."); see also Inter-American Convention on the Prevention, Punishment, and Eradication of Violence Against Women, Art. 4, June 9, 1994, 33 ILM 1534 (recognizing women's right "to have equal access to the public service of her country and to take part in the conduct of public affairs, including decision-making.”); African Charter on Human and Peoples' Rights, Arts. 13, 18, June 27, 1981, 1520 UNTS 217, 21 ILM 58 (All citizens shall have "the right of equal access to the public service of his country" and the "State shall ensure the elimination of every discrimination against women."); Protocol to the African Charter on Human and Peoples' Rights on the Rights of Women in Africa, Art. 9(2), July 11, 2003, OAU Doc. CAB/LEG/66.6/Rev. 1, at http://www.achpr.org/instruments/women-protocol/ ("States Parties shall ensure increased and effective representation and participation of women at all levels of decision-making."); Protocol No. 12 to the Convention for the Protection of Human Rights and Fundamental Freedoms, Art. 1, Apr. 4, 2000, ETS No. 177 (" 1 . The enjoyment of any right set forth by law shall be secured without discrimination on any ground 
to women, on equal terms with men and without any discrimination, the opportunity to represent their Governments at the international level and to participate in the work of international organizations." ${ }^{28}$ Article 7 provides that states must take measures to "eliminate discrimination against women in the political and public life of the country and, in particular, shall ensure to women, on equal terms with men, the right . . . to hold public office and perform all public functions at all levels of government." 29 The 1995 Beijing Declaration and Platform for Action, endorsed by 189 countries, emphasized the importance of the full participation of women in decision making, calling for equal opportunities and participation of the sexes "in all national, regional and international bodies and policy-making processes." ${ }^{30}$ In International Labour Organization Convention 111, 172 states parties took on the legally binding obligations to formulate and implement national policies to promote equal opportunity and treatment in respect of employment, to modify administrative practices inconsistent with these goals, and "to pursue the policy in respect of employment under the direct control of a national authority." 31

Not only are states legally obligated to ensure that both men and women are given equal opportunities to participate; the legitimacy of international courts can be adversely affected by sex-unrepresentative benches. Conversely, this legitimacy can be enhanced by more representative benches. International courts exercise public authority, and their authority requires justification. ${ }^{32}$ These institutions play a vital role in the development and application of the rules that govern interstate relations as well as in human rights and international criminal law. They decide when the use of force is prohibited, what natural resources belong to which states, what constitutes a violation of the world's trade laws, what conduct qualifies as an international crime or violation of human rights, and how to remedy breaches of international law. Traditional sources of justification for these institutions' authority — primarily state consent and procedural fairness to the litigants — are insufficient to ground their legitimacy, and alternative sources of justification are necessary. ${ }^{33}$

Representativeness is a democratic value that can serve to justify the exercise of authority. ${ }^{34} \mathrm{An}$ ICC bench composed of judges only from Italy would be problematic because the world is not composed entirely of Italians. A bench composed entirely of women would be problematic because half of the world's population is male. Significant underrepresentation of the world's population can

such as sex, race, colour, language, religion, political or other opinion, national or social origin, association with a national minority, property, birth or other status. 2. No one shall be discriminated against by any public authority on any ground such as those mentioned in paragraph 1.").

${ }^{28}$ Convention on the Elimination of All Forms of Discrimination Against Women, Art. 8, Mar. 1, 1980, 1249 UNTS 13; Claudia Martin, Article 8 of the Convention to Eliminate all Forms of Discrimination Against Women: A Stepping Stone in Ensuring Gender Parity in International Organs and Tribunals (n.d.), at http://www. gqualcampaign.org/wp-content/uploads/2015/09/Advocacy-Piece-1.pdf.

29 Convention on the Elimination of All Forms of Discrimination Against Women, supra note 28, Art. 7.

30 Beijing Declaration, para. 36 (Sept. 15, 1995), in Report of the Fourth World Conference on Women, supra note 25, ch. I, Res. 1, Annex I.

31 Convention Concerning Discrimination in Respect of Employment and Occupation (No. 111), Arts. 2-3, June 25, 1958, 362 UNTS 31; Ratifications of C111, at http://www.ilo.org.

32 Gráinne De Búrca, Developing Democracy Beyond the State, 46 Colum. J. TranSNAT'L L. 221, 226-27 (2008). Armin von Bogdandy \& Ingo Venzke, On the Democratic Legitimation of International Judicial Lawmaking, 12 GERMAN L. J. 1341, 1343 (2011).

33 Nienke Grossman, The Normative Legitimacy of International Courts, 86 TEMP. L. REV. 61, 68-76 (2013); Armin von Bogdandy \& Ingo Venzke, In Whose Name? An Investigation of International Courts' Public Authority and Its Democratic Justification, 23 EUR. J. INT'L L. 7, 8 (2012).

${ }^{34}$ Nienke Grossman, Sex on the Bench: Do Women Judges Matter to the Legitimacy of International Courts?, 12 CHI. J. INT'L L. 647, 668-69 (2012). 
undermine the democratic legitimacy of an institution. Furthermore, the consistent overrepresentation of one group on the bench, when not caused by limitations in the pool, raises questions about the integrity of selection procedures more generally, which can affect perceptions of a court's legitimacy. Alternatively stated, policies or procedures that result in diminished opportunities for participation of half the world's population can undermine these institutions' public authority by failing to reflect the world's population and by giving rise to actual or perceived bias.

At the international level, few studies of a gender effect of judging exist, in part because the paucity of women on the bench detracts from the statistical significance of any conclusions. ${ }^{35}$ Yet, at least one study in the investment law field and another in the international criminal law field suggest that women and men may approach some issues differently. ${ }^{36}$ Several prominent female international court judges —including Patricia Wald, Navanethem Pillay, and Cecilia Medina Quiroga - have proposed that the presence of female judges may make a difference to understanding the facts in a case and to judicial decision making. ${ }^{37}$ In any event, members of underrepresented or excluded groups, including women, will question the authority of institutions where they make up only a low percentage of top decision makers. ${ }^{38}$

A lack of gender balance on the bench also has important collateral effects. For example, more women behind the dais may result in more gender-balanced legal teams in front of it. Since the number of women on the ICJ's bench has grown from one to three out of fifteen, some of these judges have called for more diverse counsel to argue litigants' cases. A recent study showed that only four women versus fifty-nine men appeared more than once before the ICJ from 1999 to 2012..$^{39}$ (Incidentally, the paucity of women oral advocates does not explain the paucity of women on the bench since the vast majority of ICJ judges does not appear to be drawn from the ranks of oral advocates. $)^{40}$ The presence of women judges provides added justification for legal teams to look for and include more women lawyers. Also, women in positions of power may create greater mentorship opportunities and affect women's and girls' perceptions about their roles and possibilities in society. One study showed that women and girls were more likely to participate in and discuss political issues when more women were members of parliament. ${ }^{41}$

35 See Kimi L. King \& Megan Greening, Gender Justice ofJust Gender? The Role of Gender in Sexual Assault Decisions at the International Criminal Tribunal for the Former Yugoslavia, 88 SOC. SCI. Q. 1049, 1050 n.2 (2007) (not including the ICTR in a study on the gender effect of judging because "there are too few [women judges] to conduct empirical analysis and virtually all the guilty defendants received life sentences").

36 Id.; Michael Waibel \& Yanhui Wu, Are Arbitrators Political? 35 (paper presented at the ASIL Research Forum, Los Angeles CA (Nov. 3-5, 2011)), at https://www.researchgate.net/publication/256023521_Are_Arbitrators_Political.

37 Patricia Wald, Six Not-So-Easy Pieces: One Woman's Journey to the Bench and Beyond, 36 U. TOL. L. REV. 979 , 989 (2005); Patricia Wald, What Do Women Want from International Criminal Justice? To Help Shape the Law, INTLAWGRRLS (Oct. 5, 2009), at http://www.intlawgrrls.com/2009/10/what-do-women-want-from-international.html; DANiEl Terris, CESARE P.R. ROMANO \& LEIGH SWIGART, ThE INTERNATIONAL JUdGE: AN INTRODUCTION TO THE MEN AND WOMEN WHO DECIDE THE WORLD's CASES 48, 186-87 (2007) (containing comments by former ICC Judge Navanethem Pillay and former IACHR Judge Cecilia Medina Quiroga).

38 Grossman, supra note 34, at 664-65.

39 Shashank Kumar \& Cecily Rose, A Study of Lawyers Appearing Before the International Court of Justice, 25 EUR. J. INT'L L. 893, 904 (2014).

${ }^{40}$ According to the curricula vitae of the fifteen current members, available on the ICJ's website, only three have served as Counsel in cases before the ICJ: Christopher Greenwood, Giorgio Gaja, and James Crawford. Three served as agents for their states: Ronny Abraham, Peter Tomka, and Kirill Gevorgian.

${ }^{41}$ Christina Wolbrecht \& David E. Campbell, Leading by Example: Female Members of Parliament as Political Role Models, 51 AM. J. POL. SCI. 921-39 (2007); see also, e.g., Kijana Crawford \& Danielle Smith, The We and the 


\section{STEPS FOR ACHIEVING SEX-REPRESENTATIVE BENCHES}

\section{Greater Transparency at the National Level and Institutionalized Screening at the International Level}

States have both legally binding obligations and non-legally binding reasons for supporting balanced benches. But what concrete steps can they take? First, states can make national nomination procedures more transparent and open. Of the twelve courts surveyed, as shown in Table 1 above, a great majority had closed, opaque national nomination procedures. As regards many international courts, little to no statutory or other guidance to states exists for selecting candidates at the national level. States are left to craft their own procedures, with no international or domestic oversight. Even on courts where some guidance is provided (such as the ICC and ICJ), scholars have raised doubts that it is followed. A series of interviews about selection procedures on these courts showed that "few well-informed insiders appear to be familiar with the details," 42 and processes varied significantly across states and were "marked by their lack of transparency and accountability." ${ }^{43}$ One interviewee described the process of nominating judges to the ICJ and ICC as "not very institutional-like, [more] a friendship thing." ${ }^{44}$ Others wrote that "one cannot apply to become an international judge" but rather must be "called" and that perhaps the most important factor is "being on the radar screen of, and appreciated by, one's own government, particularly by some key civil servants." ${ }^{45}$

The opacity and closed nature of national nomination procedures facilitate the nomination of well-connected insider candidates. Nominators have little incentive to move beyond their personal networks or to refrain from acting in a self-interested way by nominating individuals who can help them professionally in the future or validate their own qualifications. Twenty years ago, Yves Dezalay and Bryant Garth wrote that international commercial arbitrators "promote the forms of symbolic capital that give maximum value to their personal characteristics, but also they try to build symbolic capital that will allow them to prosper and succeed in the changing environment." 46 The same motivations likely apply to international court nominators. Further, access to the kinds of experiences that build symbolic capital may themselves be subject to similar gatekeeping. For example, few women have served on the International Law Commission, but four of the last five judges elected to the ICJ spent time on that body. ${ }^{47}$ Without transparency and openness, not only is it difficult for potential candidates to apply, but also no accountability exists for nominators.

In response to these shortcomings, states can take concrete steps to publicize openings on international courts and to craft national nomination procedures with explicit and publicly known standards and time-lines. The Parliamentary Assembly and Committee of Ministers of the Council of Europe have led the way in this regard with respect to the ECHR. For example,

Us: Mentoring African American Women, 36 J. BLACK STUD. 52 (2005) (referring to the importance of mentoring to the career development of African American female administrators in higher education).

42 MACKENZIE et al., supra note 16, at 64-65.

43 Id. at 95 .

${ }^{44}$ Id. at 86.

45 TERRIS et al., supra note 37 , at 23.

46 YVES DEZALAY \& BRYANT G. GARTH, DEALING IN VIRTUE: INTERNATIONAL COMMERCIAL ARBITRATION AND THE CONSTRUCTION OF A TRANSNATIONAL LEGAL ORDER 10, 29 (1996).

47 International Law Commission, Membership (2012-2016), at http://legal.un.org/ilc/ilcmembe.shtml. 
the committee urged states to make the procedure for eliciting applications "stable and established in advance through codification or by settled administrative practice," and to publicize its details in the call for applications, on government websites, and wherever else may be relevant. ${ }^{48}$ The call for applications should be made widely and publicly available so that "it could reasonably be expected to come to the attention" of suitable candidates. ${ }^{49}$ The committee noted that additional measures may be appropriate to raise awareness of the call for applications - such as acting to encourage interest on the part of women and ethnic or other minorities that are less likely to apply for ECHR judgeships. ${ }^{50}$ Other examples of measures included maximizing transparency in selection, raising awareness about the work and life of judges in Strasbourg, public lectures, placing articles or interviews in journals and in wider media, and speeches and interventions by sitting or former judges. ${ }^{51}$ States could create selection committees to consider and vet nominees. They could be obliged to provide information to other states, court registries, and relevant assemblies of states parties or the general public about the procedures used to select candidates, specifying what considerations they took into account.

At the international voting level, screening committees could be established to vet and recommend candidates for election. Such screening may be correlated with greater representation of women on the bench. For example, as demonstrated in Table 1 above, three of four courts that utilize institutionalized screening mechanisms to interview and evaluate candidates had relatively high numbers of female judges in mid 2015 or high percentages of slots occupied by women since 1999 or since establishment, whichever came later. The courts were the ICC, ECHR, and ECOWAS, with 39 percent, 33 percent, and 14 percent of women serving on the bench in mid 2015, respectively. Historically, women have occupied 47 percent of the slots on the ICC, 29 percent on the ECHR, and 40 percent on ECOWAS. The fourth court with screening, the WTO Appellate Body, had only 14 percent women judges in mid 2015, and women occupied 17 percent of judicial slots since its establishment. Nonetheless, the courts with the lowest percentages of women on the bench since establishment included those with the least amount of screening, such as the Andean Tribunal of Justice (12 percent), IACHR (10 percent), ICJ (3 percent), and ITLOS (2 percent).

The ECHR and ICC are two potential models for institutionalized candidate screening. The Assembly of State Parties created an Advisory Committee on Nominations to the ICC, which assesses whether nominees meet the Rome Statute's requirements. ${ }^{52}$ It conducts interviews and makes determinations about the extent of candidates' knowledge and experience, as well as their proficiency in the Court's working languages. ${ }^{53}$ The Parliamentary Assembly of the Council of Europe called for the vetting of nominees, starting in 1996, through both

48 Council of Europe, Committee of Ministers, CM(2012)40 Addendum Final, 4.4 Guidelines of the Committee of Ministers on the Selection of Candidates for the Post of Judge at the European Court of Human RightsExplanatory Memorandum, pt. C(III)(1) (Mar. 29, 2012).

49 Id., pt. C(III)(2).

50 Id., para. 42.

51 Id., para. 43.

52 International Criminal Court, Assembly of States Parties, 10th Sess., Report of the Bureau on the Establishment of an Advisory Committee on Nominations of Judges of the International Criminal Court, ICC Doc. ICCASP/10/36 (Dec. 21, 2011).

53 International Criminal Court, Assembly of States Parties, 12th Sess., Report of the Advisory Committee on Nominations of Judges on the Work of Its Second Meeting, ICC Doc. ICC/ASP/12/47, para. 10 (Oct. 29, 2013). 
interviews and the screening of candidates on behalf of the entire Assembly. ${ }^{54}$ A new Committee on the Election of Judges to the ECHR began operating in January 2015, and it studies standardized curricula vitae of candidates, conducts interviews, and provides recommendations and rankings of candidates. ${ }^{55} \mathrm{It}$ is also charged with ensuring that the nominating state complied with the Assembly's criteria for the establishment of lists. ${ }^{56}$

Nongovernment organizations or independent experts can encourage greater transparency at the national level and more rigor at the international level. For example, the Open Society Justice Initiative established a panel of independent experts to assess and recommend candidates to the IACHR. ${ }^{57}$ The Coalition for the International Criminal Court played a similar role in vetting nominees until the creation of the Advisory Committee on Nominations. ${ }^{58} \mathrm{UN}$ treaty bodies with relevant mandates could also assist in monitoring states' obligations to ensure equal opportunity to participate in the conduct of public affairs. For example, the Committee on the Elimination of Discrimination Against Women and the Human Rights Committee of the United Nations could question states on their international judge-nominating and -voting procedures as they monitor the implementation of the Convention on the Elimination of Discrimination Against Women and of the International Covenant on Civil and Political Rights, respectively. ${ }^{59}$

\section{Aspirational Statements for Gender Balance or Quotas}

Although enhanced openness and transparency at the domestic level and screening at the international level may lead to better gender balance on the bench, states may on occasion have reasons to oppose such measures. For example, if states wish to control tightly the nomination process and to screen their own candidates for ideological reasons, they will hesitate to create screening committees or to open up domestic nomination processes. But when states view courts and judges as "trustees" of specific normative regimes or when they wish to demonstrate their commitment to judicial independence, they may favor open national nominations and international screening procedures. ${ }^{60}$ Aspirational statements for gender balance on the bench or quotas are alternative policy choices for states wishing to increase the percentage of women on the bench. Of the five courts with the highest percentage of women on the bench from 1999 to 2015 , four had either aspirational statements for inclusion or quotas (see Table 1). None of the seven courts with the lowest percentages of women on the bench had either. In mid 2015, women made up 32 percent of benches with such requirements and only 15 percent of benches without them.

54 Eur. Parl. Ass. Res. 1082, Procedure for Examining Candidatures for the Election of Judges to the European Court of Human Rights (Apr. 22, 1996).

55 Eur. Parl. Ass. Res. 2002, Evaluation of the Implementation of the Reform of the Parliamentary Assembly (June 24, 2014).

56 Id.

57 FINAL REPORT OF THE INDEPENDENT PANEL FOR THE ELECTION OF INTER-AMERICAN COMMISSIONERS AND JUDGES, supra note 17.

58 Coalition for the International Criminal Court, $>$ Delivering on the Promise of a Fair, Effective and Independent Court > Election of ICC and ASP Officials > Judges, at http://www.iccnow.org/?mod=electionjudges.

59 See supra part III.

60 See Karen J. Alter, Agents or Trustees? International Courts in Their Political Context, 14 EUR. J. INT'L REL. $33,35,39-40$ (2008). 
States have chosen to use aspirational statements for greater balance on the bench on at least three occasions with respect to the African Court on Human and Peoples' Rights and ad litem judges on the ICTR and ICTY. These statements signal to states that sex representativeness is a priority for the states parties to the relevant court. The African Court's statute provides that at the international election stage, states must ensure that "there is representation of the main regions of Africa and of their principal legal traditions" and also that there is "adequate gender representation." "F1 For ad litem judges on both international criminal tribunals, nominating states are required to take "into account the importance of a fair representation of female and male candidates." 62 Two slots of eleven have been held by women on the African Court since its establishment in 2006, but one can only speculate on what the numbers would have been in the absence of the statutory language. Between 1999 and 2015, a much higher percentage of women have served on the ad litem benches of the ICTR and ICTY than on their permanent benches. During this period, women occupied 22 percent of permanent judge slots and 35 percent of ad litem slots on the ICTR. On the ICTY, 11 percent of permanent judge slots went to women versus 41 percent of ad litem slots. These numbers suggest that even a political commitment to some form of parity can have meaningful consequences.

Quotas or temporary special measures appear effective at getting women on the bench. Unsurprisingly, the courts with quotas or virtual quotas have among the highest percentages of women on the bench. The Rome Statute of the International Criminal Court provides that states must take into account a "fair representation of female and male judges" when voting. ${ }^{63}$ If less than twice as many candidates are available than the number necessary to fulfill gender (and regional) voting requirements, the president of the Assembly of States Parties may extend the nomination period up to six weeks. ${ }^{64}$ At the voting stage, each state party is required to vote for a minimum number of candidates of each gender, and only ballots complying with all the various voting requirements - including gender representation — are valid. ${ }^{65}$ The percentage of women on the ICC has never dropped below 39 percent since establishment, and 47 percent of all judicial slots have gone to women since establishment.

On the ECHR, as soon as the Parliamentary Assembly of the Council of Europe began bringing attention to the issue of sex representation in 1996, the percentage of women on the bench jumped from 3 percent in 1997 to 18 percent in 1998. In 2004, the Parliamentary Assembly decided that it would no longer consider unisex lists of candidates for election to the ECHR. ${ }^{66}$ The percentage of women judges rose from 23 percent in 2004 to a peak of 40 percent in 2011. After Malta refused to include a female on its three-candidate list, the ECHR issued an advisory opinion in 2009 that prohibited the Parliamentary Assembly from rejecting candidate lists when nominating states have taken "all the necessary and appropriate steps" to

${ }^{61}$ Protocol to the African Charter on Human and Peoples' Rights on the Establishment of an African Court on Human and People's Rights, Art. 14(2), (3), June 10, 1998, OAU Doc. OAU/LEG/EXP/AFCHPR/PROT (III), at http://www.achpr.org/instruments/court-establishment/.

62 Updated Statute of the International Criminal Tribunal for the Former Yugoslavia, Art. 13 ter(1)(b) (Sept. 2009), at http://www.icty.org/sid/135; Statute of the International Tribunal for Rwanda, Art. 12 ter(1)(b) (as amended, Jan. 31, 2010), at http://unictr.unmict.org/en/documents/statute-and-creation.

63 Rome Statute of the International Criminal Court, supra note 23, Art. 36(8)(a)(iii).

64 International Criminal Court, Assembly of States Parties, Procedure for the Nomination and Election of Judges of the International Criminal Court, Res. ICC-ASP/3/Res.6, para. 11 (Sept. 10, 2004).

${ }^{65} I d$., paras. 20, 22.

66 Eur. Parl. Ass. Res. 1366, Candidates for the European Court of Human Rights (Jan. 30, 2004). 
ensure that candidate lists include a member of the underrepresented sex, especially following an open and transparent procedure including a call for candidates. ${ }^{67}$ Despite the softening of the list requirement, women made up 33 percent of the bench in mid 2015. From 1999 to 2015, women occupied 29 percent of judicial slots on that court.

Counter-arguments to the use of these measures include that they are appropriate only when "women's concerns" are a meaningful component of the subject-matter jurisdiction of a court, when women and men judge differently, or only when those women elected "represent" women in their decision making. These arguments are flawed. The decisions of international courts on international economic law, maritime delimitation, and the use of force affect both men and women, and fall within the exclusive domain of neither. They are equally both men's and women's concerns. Whether or when men and women judge differently is irrelevant. States have committed themselves to giving men and women equal opportunities to participate in governance at all levels, through the Convention on the Elimination of Discrimination Against Women, the International Covenant on Civil and Political Rights, the UN Charter, and other soft law instruments. ${ }^{68}$ No exception to these obligations can be made based on proof that men and women decide differently. Finally, women should bear no added obligation to "represent" women, particularly because no such litmus test is applied to male candidates.

Another counter-argument is that quotas put unqualified women on the bench and thereby detract from a court's authority or legitimacy. First, as discussed above, qualifications do not appear to be the primary driving factor in many international judicial elections in the first place. Second, while some have blamed efforts at parity when a less qualified woman has been elected to the bench, they do not appear to fault gender when a less qualified man is elected; instead, such an election is attributed to other causes, such as a flawed selection procedure. Perhaps most persuasive, the data suggest that qualified women are being kept off the bench and not that unqualified women are being put on it. Eight of twelve courts surveyed in mid 2015 had lower percentages of women on the bench than in previous years, although one can reasonably assume that more qualified women are available today than in the past. And countries where women are prestigious lawyers, judges, and academics have failed to put women on international court benches at all or in any meaningful way.

\section{CONCLUSION: THE POLITICAL WILl FOR REFORM}

Does the political will exist to make the necessary reforms to achieve sex-representative international court benches? Individuals interviewed about selection procedures on the ICC and ICJ, while enthusiastic about the need for geographical diversity, were "ambivalent" about the need to include more women on the bench. ${ }^{69}$ States appear to support gender balance on the bench more widely for human rights courts and international criminal courts, as demonstrated by the institution of gender balance quotas and the requirement that states take a fair representation of male and female members into account for many of these courts. Nonetheless, the

${ }^{67}$ Advisory Opinion on Certain Legal Questions Concerning the Lists of Candidates Submitted with a View to the Election of Judges to the European Court of Human Rights, 49 Eur. Ct. H.R. 33, para. 54 (Grand Chamber 2009).

68 See supra part II.

69 MACKENZIE et al., supra note 16, at 48-49. 
IACHR has no such quotas or aspirational statements. It is rare to hear focused criticism of the sex-skewed ITLOS or WTO Appellate Body.

Yet, at the same time, awareness and recognition appear to be growing among many in the international community that sex representativeness is an important goal to aspire to on bodies involving international law and relations. Various voluntary gender-balance or parity initiatives have taken off recently. An example is the International Geneva Gender Champions initiative, launched in July 2015, which gives heads of international organizations and representatives of missions in Geneva the opportunity to commit publicly to strive for gender parity on panels and to undertake two additional "concrete, measurable, accountable institutional actions" in one year "to advance gender equality," either in executive management or in programmatic work. ${ }^{70}$ Possible commitments include supporting the advancement of female colleagues and working towards gender parity in delegations to the United Nations. ${ }^{71}$ Among its signatories are the director general of the UN office in Geneva, Michael Møller, U.S. Ambassador Pamela Hamamoto, and at least seventy other ambassadors and chiefs of international organizations in Geneva. ${ }^{72}$

The Gqual Campaign for Gender Parity in International Representation, launched in September 2015 at the United Nations in New York, seeks to achieve parity on international lawmaking and influencing bodies, including international courts, tribunals, and treaty-monitoring bodies. ${ }^{73}$ Its founding document — signed by hundreds of individuals, including academics, high-level state officials, and members of many of these bodies_calls for the establishment of mechanisms at the national and international levels to establish gender parity and seeks to obtain pledges from states to nominate and vote in parity. ${ }^{74}$ In the same vein, in September 2015, the Human Rights Council of the United Nations reaffirmed that "the active participation of women, on equal terms with men, at all levels of decision-making, is essential to the achievement of equality, inclusive economic growth and sustainable development, peace and democracy," and "the obligation of States to take all appropriate measures to ensure that every citizen has an effective right and opportunity to equal participation in public affairs."75

Twenty-five years ago, "Feminist Approaches to International Law" challenged us to rethink and re-evaluate the structures and substance of international law through a feminist lens. While progress has undoubtedly been made in the last quarter century, much remains to be accomplished. Achieving sex-representative international court benches will bring states into compliance with their international legal obligations, enhance the legitimacy of international courts, and advance the project of equality of the sexes in international institutions.

70 International Geneva Gender Champions, at http://genevagenderchampions.com/. The documents cited below can be obtained through the main Web page.

71 International Geneva Gender Champions, Commitments.

72 International Geneva Gender Champion, Champions.

73 Gqual. The Campaign: An Overview, at http://www.gqualcampaign.org/our-work/. The documents cited below can be obtained through the main Web page.

${ }^{74}$ Gqual. The Gqual Declaration; Gqual. The Signatures.

${ }^{75}$ Human Rights Council, Equal Participation in Political and Public Affairs, pmbl., para. 3, UN Doc. A/HRC/ 30/L.27/Rev.1 (Sept. 30, 2015). 